\title{
Effect of Long Term Reverse Feeding on the Reproductive and Non-reproductive Tissues in Male Mice
}

\author{
Eun Hye Go and ${ }^{\dagger}$ Sung-Ho Lee \\ Department of Life Science, Sangmyung University, Seoul 110-743, Korea
}

\begin{abstract}
Previously, we demonstrated that the shift and/or restriction of feeding time during relatively short-term period (4 weeks) could alter the pituitary gonadotropin expression and the weights of seminal vesicle and prostate in rats. We also found that the reverse feeding (RF) schedule (up to 8 weeks) might induce an adaptable metabolic stress and cause impairment of androgen-dependent reproductive tissues. In the present study, we extended the RF time regimen up to 12 weeks, and measured the reproductive tissue weights. After 4 and 8 weeks of RF, the weights of epididymis were not significantly different. After 12 weeks, however, epididymis weights of RF animals were significantly different (CON 12W : $\mathrm{RF} 12 \mathrm{~W}=48.26 \pm 0.62 \mathrm{mg}: 44.05 \pm 1.57 \mathrm{mg}, p<0.05)$. After 4 and 12 weeks of feeding, seminal vesicle weights of $\mathrm{RF}$ animals were significantly decreased (CON $4 \mathrm{~W}: \mathrm{RF} 4 \mathrm{~W}=79.36 \pm 8.34 \mathrm{mg}: 46.28 \pm 2.43 \mathrm{mg}, p<0.001$; $\mathrm{CON} 12 \mathrm{~W}: \mathrm{RF} 12 \mathrm{~W}=$ $72.04 \pm 3.76 \mathrm{mg}: 46.71 \pm 2.27 \mathrm{mg}, p<0.001$, respectively). Prostate weights were not changed by RF. Kidney and spleen weights of RF animals were significantly different on weeks 4 and 12 (Kidney, CON 4W : RF 4W $=249.72 \pm 4.20 \mathrm{mg}$ : $228.41 \pm 3.03 \mathrm{mg}, p<0.001$; CON $12 \mathrm{~W}: \mathrm{RF} 12 \mathrm{~W}=309.15 \pm 7.49 \mathrm{mg}: 250.72 \pm 6.13 \mathrm{mg}, p<0.001$, respectively, Spleen, CON $4 \mathrm{~W}: \mathrm{RF} 4 \mathrm{~W}=111.26 \pm 3.76 \mathrm{mg}: 96.88 \pm 4.69 \mathrm{mg}, p<0.05$; CON $12 \mathrm{~W}: \mathrm{RF} 12 \mathrm{~W}=123.93 \pm 10.72 \mathrm{mg}: 94.68 \pm 5.65 \mathrm{mg}, p<0.05$, respectively). Histology analysis of seminal vesicle revealed that the thinner epithelial cell layers, reduced complexities of swollen papilla folding in the exocrine glands on weeks 4 and 12 of RF. There was no histological difference between control and RF group on week 8 . The present study indicates that up to 12 weeks RF induced differential changes in tissue weights of male mice. In particular, seminal vesicle, kidney and spleen seemed to temporarily adapted to the RF-induced metabolic stress on week 8 of feeding schedule. These results confirmed the our previous study that the RF might induce an adaptable metabolic stress and cause impairment of androgen-dependent reproductive tissues such as epididymis and seminal vesicle as well as non-reproductive tissues such as kidney and spleen. Further studies will be needed to achieve a better understanding of the how does mealtime shift affect the reproductive function and exact nature of adaptation.
\end{abstract}

Key words : Reverse feeding (RF), Male mice, Tissue weight, Seminal vesicle, Circadian rhythm

\section{INTRODUCTION}

Animals have developed a range of strategies to ensure reproductive success, among them, circadian rhythms are most important for the control and/or maintenance of reproductive function (Boden et al., 2013). However, many of the mice with disrupted 'clock genes' failed to show overt reproductive failure, so there might be alternative or compensatory processes (Boden \& Kennaway, 2006). For example, internal cue such as energy balance might be

\footnotetext{
Manuscript received 4 August 2014, Received in revised form 11 August 2014, Accepted 18 August 2014

${ }^{\dagger}$ Corresponding Author : Sung-Ho Lee, Department of Life Science, Sangmyung University, Seoul 110-743, Korea. Tel. : +82-2-2287-5139, E-mail : shlee@smu.ac.kr

This is an Open Access article distributed under the terms of the Creative Commons Attribution Non-Commercial License (http:// creativecommons.org/licenses/by-nc/3.0) which permits unrestricted non-commercial use, distribution, and reproduction in any medium, provided the original work is properly cited.
} 
simultaneously participated in the regulation of reproductive system (Sinchak \& Wagner, 2012; Wahab et al., 2013).

Metabolic stresses are frequently coupled to disturbed reproductive maturation and even infertility (Castellano et al., 2009). In male rats, food restriction ( $\geq 50 \%$ ) decreased serum testosterone and LH levels resulting negative effects on androgen-dependent reproductive organs (Grewell et al., 1971; Howland, 1975; Glass et al., 1986; Santos et al., 2004). Previously we demonstrated that the shift and/or restriction of feeding time during relatively short-term period ( 4 weeks) could alter the pituitary gonadotropin expression and the weights of seminal vesicle and prostate in rats (Kwak \& Lee, 2012). In the following study, we found that reversed feeding schedule (up to 8 weeks) might induce an adaptable metabolic stress and cause impairment of androgen-dependent reproductive tissues (Jeon \& Lee, 2012).

To further confirm our hypothesis that this reverse feeding (RF) regimen could induce adaptable physiological patterns as shown in shift workers, we extended the RF time regimen up to 12 weeks. For the convenience of experiments, we used mouse model and measured the general and reproductive indices of the animals.

\section{MATERIALS \& METHODS}

\section{Animals}

Male ICR mice were obtained from DBL (Chungcheongbuk-do, Korea) and reared 2 weeks in Sangmyung University animal facility under conditions of 12-h light/ dark cycle (lights on at 07:00 h) and constant temperature of $22 \pm 1^{\circ} \mathrm{C}$. All procedures used were approved by the Animal Care and Use Committee at Sangmyung University in accordance with guidelines established by the Korea Food and Drug Administration (R-1203).

\section{Experimental design}

Four weeks after birth, male mouse were divided into two groups. The animals of night feeding group (night feeding, CON group) have restricted access to food during night time (17:00-21:00) for 4,8 and 12 weeks, respectively. The day feeding animals (reverse feeding, RF group) have restricted access to food during daytime (09:00-13:00) for 4, 8 and 12 weeks, respectively. All animals were allowed to drink freely. When the feeding schedules were over, animals were sacrificed and the tissues (testis, epididymis, seminal vesicle, prostate, kidney, adrenal and spleen) were removed and weighed.

\section{Histology}

Seminal Vesicle tissue specimens were fixed 4\% paraformaldehyde at $4^{\circ} \mathrm{C}$ for $24 \mathrm{~h}$. Fixed tissues were serially dehydrated in graded ethanol and xylene. Specimens were embedded in paraffin block. The tissues blocks were cut at $6 \mu \mathrm{m}$ using microtome (HM350S, MICROM, Germany). Sections were stained with hematoxylin-eosin (H.E.) stain and examined under light microscope (BX51, Olympus, Japan).

\section{Statistical analysis}

All values are expressed as the means ( \pm S.E.). Differences between control and treatment groups were analysed by Student's $t$-test. $P$ values less than 0.05 were considered significant. The IBM PC programs INSTAT and PRISM 3.0 (GraphPad, San Diego, CA, USA) were used to calculate and plot the results.

\section{RESULTS}

Body weights and tissue weights are shown in Fig. 1. After 4 and 12 weeks of feeding, body weights of animals from both group were not significantly different (CON $4 \mathrm{~W}: \mathrm{RF} 4 \mathrm{~W}=41.70 \pm 1.01 \mathrm{~g}: 41.00 \pm 1.29 \mathrm{~g} ; \mathrm{CON} 12 \mathrm{~W}$ : $\mathrm{RF} 12 \mathrm{~W}=36.65 \pm 0.46 \mathrm{~g}: 38.14 \pm 0.64 \mathrm{~g}$, respectively). However, 
after 8 weeks feeding, body weights of RF animals were significantly different (CON $8 \mathrm{~W}: \mathrm{RF} 8 \mathrm{~W}=43.25 \pm 0.82 \mathrm{~g}$ : $40.42 \pm 0.84 \mathrm{~g}, p<0.05)$. After 4,8 and 12 weeks of feeding, the weights of testis were not significantly different $(\mathrm{CON}$ $4 \mathrm{~W}: \mathrm{RF} 4 \mathrm{~W}=113.26 \pm 2.86 \mathrm{mg}: 116.17 \pm 1.68 \mathrm{mg} ; \mathrm{CON}$ $8 \mathrm{~W}: \mathrm{RF} 8 \mathrm{~W}=118.02 \pm 3.98 \mathrm{mg}: 118.35 \pm 2.82 \mathrm{mg} ; \mathrm{CON}$ $12 \mathrm{~W}: \mathrm{RF} 12 \mathrm{~W}=120.21 \pm 4.22 \mathrm{mg}: 112.9 \pm 4.38 \mathrm{mg}$, respecttively). After 4 and 8 weeks of feeding, the weights of epididymis were not significantly different (CON 4W : RF $4 \mathrm{~W}=41.73 \pm 1.12 \mathrm{mg}: 44.57 \pm 2.05 \mathrm{mg} ; \mathrm{CON} 8 \mathrm{~W}: \mathrm{RF} 8 \mathrm{~W}$
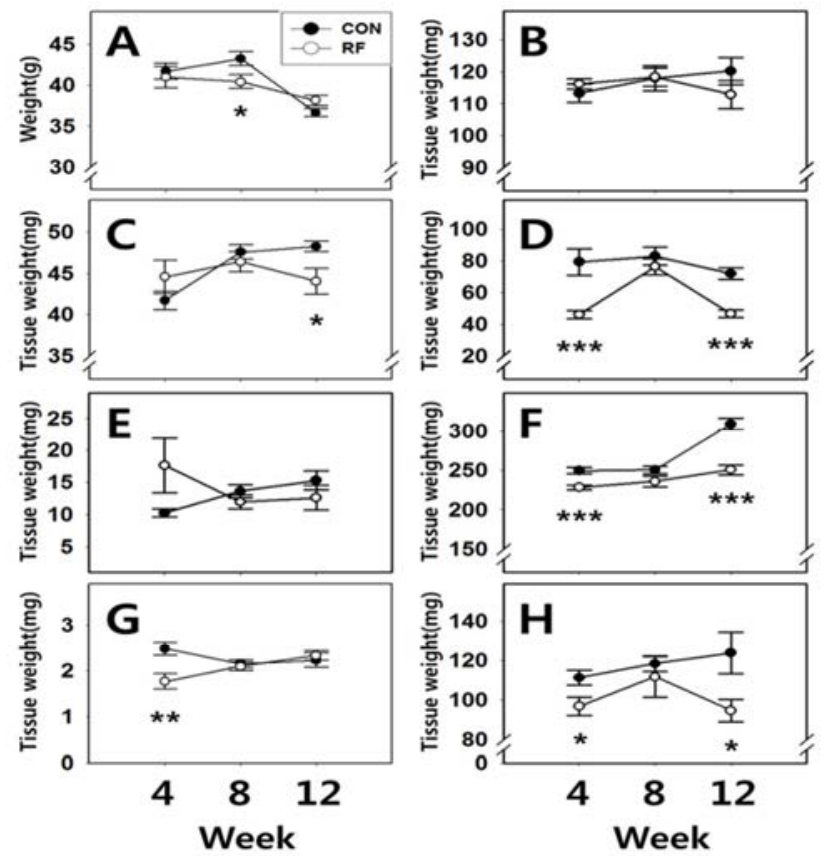

Fig. 1. Body weights, reproductive and non-reproductive tissue weights. Body weights, reproductive and non-reproductive tissue weights of night feeding (CON, control, 17:00-21:00) and reverse feeding (RF; day feeding, 09:00-13:00) male mice by cohort. Cohorts were defined by the feeding period 4, 8 and 12 weeks, respectively. Values were expressed as mean \pm S.E. A, Body weight, B, Testis, C, Epididymis, D, Seminal vesicle, E, Prostate, F, Kidney, G, Adrenal and H, Spleen. *, Significantly different from control, $p<0.05$. **, Significantly different from control, $p<0.01$. ***, Significantly different from control, $p<0.001$.
$=47.59 \pm 0.90 \mathrm{mg}: 46.43 \pm 1.21 \mathrm{mg}$, respectively). But after 12 weeks feeding, epididymis weights of RF animals were significantly different (CON $12 \mathrm{~W}: \mathrm{RF} 12 \mathrm{~W}=48.26 \pm 0.62$ $\mathrm{mg}: 44.05 \pm 1.57 \mathrm{mg}, p<0.05)$. After 4 and 12 weeks of feeding, seminal vesicle weights of RF animals were significantly different (CON 4W : RF 4W $=79.36 \pm 8.34$ $\mathrm{mg}: 46.28 \pm 2.43 \mathrm{mg}, p<0.001 ; \mathrm{CON} 12 \mathrm{~W}: \mathrm{RF} 12 \mathrm{~W}=$ $72.04 \pm 3.76 \mathrm{mg}: 46.71 \pm 2.27 \mathrm{mg}, p<0.001$, respectively). But after 8 weeks of feeding, seminal vesicle weights were not significantly different (CON $12 \mathrm{~W}: \mathrm{RF} 12 \mathrm{~W}=83.05 \pm$ $5.72 \mathrm{mg}: 76.45 \pm 5.04 \mathrm{mg})$. After 4,8 and 12 weeks of feeding, prostate weights were not significantly different $(\mathrm{CON} 4 \mathrm{~W}: \mathrm{RF} 4 \mathrm{~W}=10.26 \pm 0.66 \mathrm{mg}: 17.65 \pm 4.29 \mathrm{mg}$; CON 8W : RF 8W = 13.62 $\pm 1.04 \mathrm{mg}: 11.96 \pm 1.06 \mathrm{mg}$; $\mathrm{CON} 12 \mathrm{~W}: \mathrm{RF} 12 \mathrm{~W}=15.3 \pm 1.50 \mathrm{mg}: 12.62 \pm 1.92 \mathrm{mg}$, respectively). After 4 and 12 weeks of feeding, kidney and spleen weights of RF animals were significantly different, but not 8 weeks of feeding group (Kidney, CON 4W : RF $4 \mathrm{~W}=249.72 \pm 4.20 \mathrm{mg}: 228.41 \pm 3.03 \mathrm{mg}, p<0.001 ; \mathrm{CON}$ $8 \mathrm{~W}: \mathrm{RF} 8 \mathrm{~W}=250.51 \pm 4.45 \mathrm{mg}: 235.94 \pm 7.02 \mathrm{mg} ; \mathrm{CON}$ $12 \mathrm{~W}: \mathrm{RF} 12 \mathrm{~W}=309.15 \pm 7.49 \mathrm{mg}: 250.72 \pm 6.13 \mathrm{mg}, p<0.001$, respectively, spleen, CON 4W : RF 4W $=111.26 \pm 3.76 \mathrm{mg}$ : $96.88 \pm 4.69 \mathrm{mg}, p<0.05$; $\mathrm{CON} 8 \mathrm{~W}: \mathrm{RF} 8 \mathrm{~W}=118.48 \pm 3.98$ $\mathrm{mg}: 111.75 \pm 10.36 \mathrm{mg} ; \mathrm{CON} 12 \mathrm{~W}: \mathrm{RF} 12 \mathrm{~W}=123.93 \pm$ $10.72 \mathrm{mg}: 94.68 \pm 5.65 \mathrm{mg}, p<0.05$, respectively). After 4 weeks of feeding, adrenal weights of RF animals were significantly different $(\mathrm{CON} 4 \mathrm{~W}: \mathrm{RF} 4 \mathrm{~W}=2.48 \pm 0.15$ $\mathrm{mg}: 1.77 \pm 0.17 \mathrm{mg}, p<0.01)$. But 8 and 12 weeks of feeding, adrenal weights were not significantly different (CON 8W : $\mathrm{RF} 8 \mathrm{~W}=2.15 \pm 0.09 \mathrm{mg}: 2.09 \pm 0.09 \mathrm{mg} ; \mathrm{CON} 12 \mathrm{~W}: \mathrm{RF}$ $12 \mathrm{~W}=2.23 \pm 0.16 \mathrm{mg}: 2.33 \pm 0.11 \mathrm{mg}$, respectively).

Histological analysis of seminal vesicle revealed that the thinner epithelial cell layers of the exocrine gland on week 4 and 12 of RF. Simultaneously, the papilla parts were swollen and the complexities of folding patterns were reduced in the RF animals. There was no histological difference between control and RF group on week 8 (Fig. 2). 


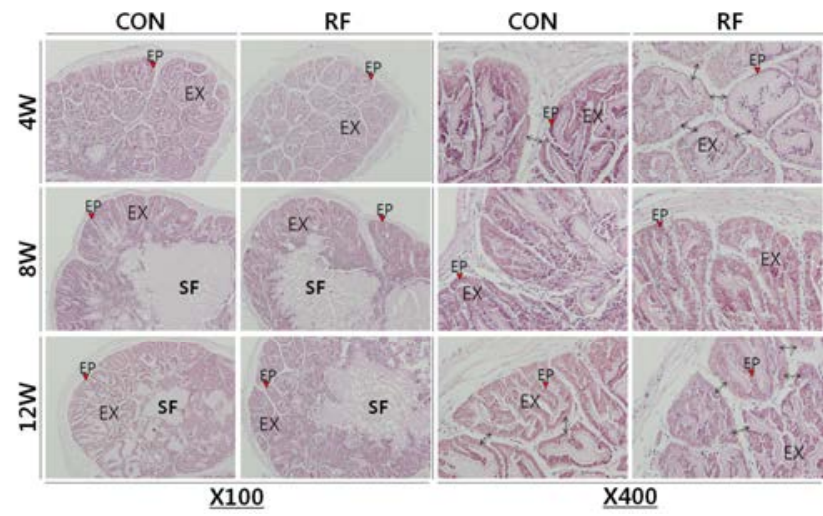

Fig. 2. Histological analysis of mice seminal vesicle. Seminal vesicles from night feeding (CON, control, 17:00-21:00) and reverse feeding (RF; day feeding, 09:00-13:00) mice were fixed. The specimens cut at $6 \mu \mathrm{m}$, then the sections were stained with hematoxylin-eosin (H.E.) stain and examined under light microscope. EP, epithelial cell; EX, papilla folding; SF, seminal fluid.

\section{DISCUSSION}

In the present study, up to 12 weeks RF induced differential changes in tissue weights of male mice. Among the reproductive tissues, the weights of testis and prostate were not altered while the weights of epididymis and seminal vesicle were significantly decreased. Interestingly, the weights of non-reproductive tissues such as kidney and spleen were also significantly decreased in RF mice. Seminal vesicle, kidney and spleen seemed to be temporarily adapted to the RF-induced metabolic stress on week 8 of feeding schedule. These results confirmed the our previous study that RF might induce an adaptable metabolic stress, disturbance of rhythmicity and cause impairment of androgendependent reproductive tissues (Jeon \& Lee, 2012).

Mammalian circadian timing system plays a major role in a wide range of reproductive function, appears to be involved in optimal reproductive performance; circadian rhythms are closely related in the control of the sperm generation (Alvarez et al., 2003), the ovarian function (Gras et al., 2012), the mating behaviour/fertilization (Refinetti, 2005), the implantation (Akiyama et al., 2010), the placental activities (Wharfe et al., 2011), the fetal development and the timing of birth (Cagnacci et al., 1998). A light entrainable circadian pacemaker (i.e. a classic master clock) is located in the suprachiasmatic nucleus $(\mathrm{SCN})$ receiving retinal inputs and sending neural outputs into pineal gland and peripheral tissues (i.e. a peripheral clock) (Boden \& Kennaway, 2006). Interestingly, the induction of food entrainable oscillator (FEO) by daily feeding schedules does not require the SCN, but FEO do exhibit defining properties of circadian clock control since the SCN lesion could not abolish the properties (Mistlberger, 2011). Actually, shifts in usual meal time profoundly affects daily rhythms such as body temperature, along with the alterations in daily rhythms of blood glucose and triglyceride levels, leading to some metabolic consequences (Yoon et al., 2012). A food-entrainable oscillator may integrate circadian rhythms, including pituitary hormone secretions, with food availability (Martínez-Merlos et al., 2004; Gooley et al., 2006; Glad et al., 2011). Previously, we also demonstrate that the shift and/or restriction of feeding time could alter the pituitary gonadotropin expression and the weights of seminal vesicle and prostate in rats (Kwak \& Lee, 2012).

Studies on the circadian adaptation in a 'swing shift' schedule of oil industry workers demonstrated that the subjects adapted to the night shift but very large individual variations were seen during the day shift (Gibbs et al., 2002). The workers could be classified as 'well-' and 'illadapted' to a shift work schedule. The present study suggests that mealtime shift might induce chronologically and tissue specifically following three phases; the early disturbed phase, adapted phase, and finally, late disturbed phase. Shift and night work generally promotes changes in feeding patterns, resulting in increased food intake during the normal resting phase usually in nighttime like our RF mice model (Knutsson, 2003; Vener et al., 1989; Pasqua et 
al., 2004). The shift workers seem to have developed mechanisms which allow them to cope with disruptions to lifestyle and the endogenous body clock (Reilly et al., 1997). They seem to be more vulnerable to some adult onset diseases such as hypertension, metabolic syndrome, cancer, and others caused by lowered immune function (Salgado-Delgado et al., 2010). Indeed, the present study revealed that the decreased spleen weights in RF mice. Our results that the seminal vesicle function could be also affected by RF suggest similar phenomena may occurred in shift workers. Hypospermia is the medical term when a man has an unusually low ejaculate/semen volume(less than $1.5 \mathrm{~mL}$ ), and would be a factor in infertility when the oligospermia is combined (Cooke et al., 1995). Instead, hyperspermia could be an impeding factor for quality of life, because it lowers male sexual performance and satisfaction. Further studies will be needed to achieve a better understanding of the how does mealtime shift affect the reproductive function and a efficient coping with the health problems of shift workers.

\section{ACKNOWLEDGEMENT}

This work was supported by a 2012 Research Grant from Sangmyung University (2012-A000-0120).

\section{REFERENCES}

Akiyama S, Ohta H, Watanabe S, Moriya T, Hariu A, Nakahata N, Chisaka H, Matsuda T, Kimura Y, Tsuchiya S, Tei H, Okamura K, Yaegashi N (2010) The uterus sustains stable biological clock during pregnancy. Tohoku J Exp Med 221:287-298.

Alvarez JD, Chen D, Storer E, Sehgal A 2003. Non-cyclic and developmental stage-specific expression of circadian clock proteins during murine spermatogenesis. Biol Reprod 69:81-91.
Boden MJ, Kennaway DJ (2006) Circadian rhythms and reproduction. Reproduction 132:379-392.

Boden MJ, Varcoe TJ, Kennaway DJ (2013) Circadian regulation of reproduction: from gamete to offspring. Prog Biophys Mol Biol 113:387-397.

Cagnacci A, Soldani R, Melis GB, Volpe A (1998) Diurnal rhythms of labor and delivery in women: modulation by parity and seasons. Am J Obstet Gynecol 178(1 Pt 1):140-145.

Castellano JM, Roa J, Luque RM, Dieguez C, Aguilar E, Pinilla L, Tena-Sempere M (2009) KiSS-1/kisspeptins and the metabolic control of reproduction: physiologic roles and putative physiopathological implications. Peptides 30:139-145.

Cooke S, Tyler JP, Driscoll GL (1995) Hyperspermia: the forgotten condition? Hum Reprod 10:367-368.

Gibbs M, Hampton S, Morgan L, Arendt J (2002) Adaptation of the circadian rhythm of 6-sulphatoxymelatonin to a shift schedule of seven nights followed by seven days in offshore oil installation workers. Neurosci Lett 325: 91-94.

Glad CA, Kitchen EE, Russ GC, Harris SM, Davies JS, Gevers EF, Gabrielsson BG, Wells T (2011) Reverse feeding suppresses the activity of the $\mathrm{GH}$ axis in rats and induces a preobesogenic state. Endocrinology 152: 869-882.

Glass AR, Herbert DC, Anderson J (1986) Fertility onset, spermatogenesis, and pubertal development in male rats: effect of graded underfeeding. Pedriatr Res 20:11611167.

Gooley JJ, Schomer A, Saper CB (2006) The dorsomedial hypothalamic nucleus is critical for the expression of food-entrainable circadian rhythms. Nat Neurosci 9:398407.

Gras S, Georg B, Jorgensen HL, Fahrenkrug J (2012) Expression of the clock genes Per1 and Bmal1 during follicle development in the rat ovary. Effects of gona- 
dotropin stimulation and hypophysectomy. Cell Tissue Res 350:539-548.

Grewall T, Mickelsen O, Hafs HD (1971) Androgen secretion and spermatogenesis in rats following semistarvation. Proc Soc Exp Biol Med 138:723-727.

Howland BE (1975) The influence of feed restriction and subsequent re-feeding on gonadotropin secretion and serum testosterone levels in male rats. J Reprod Fertil 44:429-436.

Jeon EY, Lee SH (2012) Effect of reverse feeding on the reproductive system in male rats. Dev Reprod 16:227233.

Knutsson A (2003) Health disorders of shift workers. Occup Med 53:103-108.

Kwak BK, Lee SH (2012) Effect of feeding time shift on the reproductive system in male rats. Dev Reprod 16:53-58.

Martínez-Merlos MT, Angeles-Castellanos M, Díaz-Muñoz M, Aguilar-Roblero R, Mendoza J, Escobar C (2004) Dissociation between adipose tissue signals, behavior and the food-entrained oscillator. J Endocrinol 181:53-63.

Mistlberger RE (2011) Neurobiology of food anticipatory circadian rhythms. Physiol Behav 104:535-545.

Pasqua IC, Moreno CR (2004) The nutritional status and eating habits of shift workers: a chronobiological approach. Chronobiol Int 21:949-960.

Refinetti R (2005) Time for sex: nycthemeral distribution of human sexual behavior. J Circadian Rhythms 3:4.

Reilly T, Waterhouse J, Atkinson G (1997) Aging, rhythms of physical performance, and adjustment to changes in the sleep-activity cycle. Occup Environ Med 54:812816.

Salgado-Delgado R, Angeles-Castellanos M, Saderi N, Buijs RM, Escobar C (2010) Food intake during the normal activity phase prevents obesity and circadian desynchrony in a rat model of night work. Endocrinology 151:1019-1029.

Santos AM, Ferraz MR, Teixeira CV, Sampaio FJ, da Fonte Ramos C (2004) Effects of undernutrition on serum and testicular testosterone levels and sexual function in adult rats. Horm Metabol Res 36:27-33.

Sinchak K, Wagner EJ (2012) Estradiol signaling in the regulation of reproduction and energy balance. Front Neuroendocrinol 33:342-363.

Vener KJ, Szabo S, Moore JG (1989) The effect of shift work on gastrointestinal (GI) function: a review. Chronobiologia 16:421-439.

Wahab F, Atika B, Shahab M (2013) Kisspeptin as a link between metabolism and reproduction: evidences from rodent and primate studies. Metabolism 62:898-910.

Wharfe MD, Mark PJ, Waddell BJ (2011) Circadian variation in placental and hepatic clock genes in rat pregnancy. Endocrinology 152:3552-3560.

Yoon JA, Han DH, Noh JY, Kim MH, Son GH, Kim K, Kim CJ, Pak YK, Cho S (2012) Meal time shift disturbs circadian rhythmicity along with metabolic and behavioral alterations in mice PLos One 7(8):e44053. doi: 10.1371. 